\title{
Wyburn-Mason syndrome
}

INSERM

\section{Source}

INSERM. (1999). Orphanet: an online rare disease and orphan drug data base. Wyburn-

Mason syndrome. ORPHA:53719

Wyburn-Mason syndrome or Bonnet-Dechaume-Blanc syndrome is characterized by the association of arteriovenous malformations of the maxilla, retina, optic nerve, thalamus, hypothalamus and cerebral cortex. 